\title{
Strategies of Entry Modes: The Case of Greek Banks Entering the Albanian Market
}

\author{
Jonida Këllezi, PhD Candidate
}

European University of Tirana jonida.kellezi@uet.edu.al

Doi:10.5901/ajis.2013.v2n2p321

Abstract

The phenomenon of the globalization of services is increasing at an amazing path and the same has happened to the study related to this issue. Transition from centralized to open market economy has had a great impact in the ways countries of the Western Balkans have developed. This transformation has given many windows of opportunity to some foreign businesses to expand their activities in these countries. More specifically, the beginning of the '90s has lead many financial institutions to expand their branches in the Balkan region. Emerging markets are characterized by relatively rapid institutional change and higher rates of economic growth compared to developing countries. Obviously, economic growth in these countries is generally accompanied by trade liberalization measures. However their legal, political and financial institutions are not as mature as those prevailing in the industrialized regions of the world, and this creates an ambiguous and uncertain climate for foreign investors. During the second half of the 1990s the operations of the foreign banks in the emerging market's banking system have increased dramatically as a result of surpassing the financial repression and stagnant international financial flows. In fact, selecting overseas market and deciding on how to approach these markets are the essential elements of any international strategy. International banks enter and develop into a foreign market in different ways, but the long - term success of the banking industry does not depend solely on transaction management and extensive brand network; but still, it depends on being in the right place at the right time! The aim of this research paper is to provide explanation to the strategic process by which Greek banks cope with the institutional differences in Albania. Specifically, this study was focused in studying issues such as: Greek banks entry modes in Albania; factors motivating their expansion; time of entering the market. To attain answers to this research questions, there were conducted semi-structured interviews with marketing managers of each bank operating in Albania. The result of this study confirms what was previously confirmed from literature and other similar research projects.

Keywords: International marketing; banking sector; entry modes.

\section{Albanian Banking Industry - An Overview}

The international involvement of a firm has been described as a gradual development process. The reasons that make one firm to expand internationally may vary, but as Chetty and Hunt (2004) proclaim, in most of the time these firms have a small domestic market or no domestic market at all. However, when firms decide to expand internationally, there are three important and often faced questions: what market to enter, how to enter and more importantly when to enter.

The focus of this paper is to analyze the relationship of these three issues with one another, specifically in the case of Greek Banks that have entered in the Albanian market during the last 10-15 years.

The Albanian banking system has been transformed radically in the past years, moving from a state-owned into a privately owned banking system. Privatization of the banking system, aimed to: strengthen the financial system; reduce future possible crises and increase economic efficiency. Moving from a state into a private banking system certainly raises some issues about its functionality and the relationship between fiscal and monetary policy.

Banking Reform in Albania started in July 1992 with the creation of the Bank of Albania and all trading operations were transferred to the new bank created, the National Bank of Albania. Later on were established the commercial banks or second-tier banks. Important to note is the fact that nowadays the Albanian financial system has evolved in an impressive way. Today's competition between banks has positively affected their activities through offering a diversity of products and bank deposits. Even though the competition between banks is tough in the country, these banks have successfully kept their position in the market by focusing their activities in different market segments; by offering products with different characteristics within the same segment, or by diversifying themselves through image. 
According the Bank of Albania, during the years 1995-1996, the banking system changed its composition. New joint ventures, branches of foreign banks and private banks were introduced in the Albanian market. The expansion of the banking system with private banks brought several changes on the bank operation and services.

Today the banking system is completely privatized and it consists of 16 banks, which operate under the supervision of the Bank of Albania.

\section{Globalization of Services}

The today's market place has changed radically. The rapid developments of the technology sector and of the telecommunications infrastructure have created strong linkages between countries by affecting positively the way of doing business and by extending in this way the popularity of the benefits that are associated with the globalization effect (Taylor et al, 1999). The newest wave of globalization that is quickly being spread all over the world is the globalization of services (e.g. Financial institutions), which has enabled businesses to perform a better quality of their services, as well as has provided to them unlimited opportunities to make strategic relationship between advanced and developing nations (Gordon and Glickson, 2004).

The costs of internationalization depend on how it is phased in with other types of financial reform and particularly financial deregulation and capital account liberalization. Argentina, Spain, Portugal, etc. are some of the countries that have successfully experienced this issue and their case suggests that internationalization and domestic regulation can be mutually reinforced (Claessens and Jansen, 2000).

Important issues to be carefully considered before internationalizing a service are closely connected with the well understanding of key economic, political, social, cultural and technological environment.

\section{In What Markets do Firms Expand?}

While making strategic decision process more easily for the choice of market, it is strongly recommended to firms to choose a close physic distance country due to similarities (or knowledge) in language, culture, political systems, business practice, industrial development and educational systems; and later on, expand in longer distances. However, before entering a foreign market, a company must possess a "compensating advantage" in order to overcome the "costs of foreignness" (Buckley and Casson, 1998). Therefore, the importance of market knowledge, international contacts and skills, important international relations etc., becomes crucial in order to have an easy and successful market entry.

\section{Motivating Factors}

The concept of going global or internationally has shown to be of great interest in the early 1990. The role of trade and Banks is crucial for a deeper economic integration. Market size, the servicing of MNB, real economic growth and country risk are real economic factors that affect the entrance of these banks in foreign market. Furthermore, privatization of the local banks, presence of other MNB, the demand for MNB products, greater profitability of MNB, etc are financial factors that attract these banks for expanding abroad and lastly, international interest rate differentials and the exchange rate belong to the external economic factors that have an impact on the choice of the overseas markets.

The most important multinational Greek banks that have penetrated this sector of the Albanian market throughout the years are: Alpha Bank, Emporiki Bank, National Bank of Greece and Piraeus Group.

For the last 10 years the annual GDP in the Balkan and especially in Albania was higher than that of the EU average, and at the same time their banking sector was underdeveloped. More on this, according to Zevros (2004) this expansion was beneficial to the Greek Banks, as it enabled them to reduce their operational costs and increase their sizes.

\section{Demotivating Factors}

Bonin (2001) has identified that the banking sectors in all the transition economies are underdeveloped and the reason behind this fact is due to the legacies of the pre - transition planned economies. Hence, through developing the financial sector in these areas, it will further impact upon the inflation rates; it will control the exchange rate; privatization; legal and 
fiscal reforms in the financial arena; rehabilitation and restructuring of the banking and the industrial sector and lastly it will aim to reorient the trade partners toward more sophisticated products and Western partners (Gomel, 2002).

The main argument against market entry of foreign banks is connected with the risk that domestic financial institution would not be able to withstand increased competitive pressure and consequently might face bankruptcy. Reasons behind this fact may vary but below there will be discuss some of them.

A problem that arises while expanding overseas concerns the trading partners in the host country. For instance, collecting information before selecting a partner in the host country is especially critical since finding a reliable trading partner is one of the most difficult and challenging tasks in marketing. Nevertheless, when this situation concerns emerging markets this issue becomes even more problematic since information on firms in these areas are sparse, difficult to obtain, and in most of the time inaccurate (Nijssen et al, 1999). Therefore, when the managers in duty go into new geographic markets in which they lack local knowledge, or they lack the skills required to analyze the specific market, the consequences will be fundamental for the bank in the host country as well as the one in the parent country.

Furthermore, the presence of a foreign business in a domestic market and especially if the case concerns banks, may not always be that potential to domestic customers because foreign banks can shift funds abruptly from one market to another for risk management purposes (Song, 2004).

Even though the geographic characteristics are positive for expanding a foreign business in Albania, there are problems like the phenomenon of corruption, lacks in the property rights, characteristics of the bank sector, etc. which represent an obstacle for whomever that sees this market attractive. More on this, political changes in the country lead to serious economic reforms and consequently influence the foreigner's willingness to operate in Albania. By contrast, the situation would have been different and the country would have been perceived as worthy from the foreign businesses, if relationship between the Albanian government and foreign MNE would have been created.

\section{Entry Modes for Servicing in Foreign Markets}

The choice of entry mode depends on the benefits, revenues and costs that are associated with this choice. At the same time, entry modes differ with regard to the risks that one company has to accept and to the degree of management control that the company wants to have (Makarevitch and Enkel, 2001).

Entry modes are arrangements that a firm uses in order to market its service or product in a foreign market. However, when this option regards a servicing firm, than the decision will be a difficult one since many trades - offs between risks and return should be analyzed in detail. At the same time, other issues such as resource availability, managerial capacity, control ability etc., should be considered as well.

Four options are available to such kind of businesses that are: licensing, joint venture, sole venture and foreign direct investment. These modes of entry are grouped in the study of Makarevitch and Enkel (2001) as a high - risk and high - control entry modes.

\subsection{Licensing}

Licensing is defined as a mode of low investment and low risk/return alternative, providing in this way to the licensing firm little control. More on this, it allows others to use ones know - how experience for a fee or for something else that is of value to both parties (Nissen, 2002).

\subsection{Sole Venture}

Sole venture is viewed to be of superior choice because it allows investing firms to maximize the returns on ownership specific advantage. More on this, it is considered as a high investment and high risk/return alternative that provides to firms with a considerable degree of control (Jiang, 2000). When starting a new venture, one company has to deal with the whole array of question that arise when establish a new business as well as it has a plausible business concept and a careful market analysis (Makarevitch and Enkel, 2001). All this information that will be acquired during the early years of operations will be of great usage in the near future, since the company is able to understand and research the market since at the early stages and thus becoming very familiar with it. But on the other hand, this is a long and risky procedure that if not performed with caution may bring negative results to the business. Djankov, et al (2001) proclaims that countries differ one from another in the way in which they regulate the entry of new businesses in their market and 
specifically these differences refer to the number of procedures, official time and official costs that a start up must bear before it can operate legally. Instead, with the help of a local business all these costs and risks would be minimized but still even though this type of alliance would be beneficial, many businesses and especially those that belong in the servicing industry do not follow it in most of the time but they prefer entering alone a foreign market.

Interestingly, our research has pointed out that the largest part of MNO operating in Albania, and especially all the Greek banks, being Emporiki, NBG ,Alpha Bank, Piraeus Group have entered the Albanian market through a sole venture. According to our research (interview based), the reasons for this choice of entry mode, were mostly because sole venture allowed them to maximize their returns; it gave the right to the back home bank to have fully / better control over its subsidiaries; and the last factor, concerned the learning experience.

\subsection{Joint Venture}

The joint ventures modes are formed by more than one firm. They generally have a financial interest and a board membership. A joint venture is an arrangement where the firm is required to share equity and control of the venture with a partner from the host country. This entry mode requires lower investment compare to the other modes available. As a result out of this, it provides risk, return and control commensurate to the extent of equity participation of the investing firm (Taylor et al (2000)

Much of the modernization and privatization initiatives in Albania are due to the international organizations, which has entered into the Albanian market mostly through joint venture. Those who mostly have used this type of entry mode belong to the telecommunication sector. Foreign companies have used home companies' know - how and experience to make a successful entry strategy in this market.

\subsection{Foreign Direct Investment}

As far as FDI concerns, Mukherjee and Mukherjee (2003) have pointed out that many developing countries refer to this mode of entry as a vehicle of technology transfer, which will encourage the host country to liberalize its economy by allowing multinational firms to open subsidiaries with the purpose of attracting foreign investments. Specifically, there is needed macro economy stability since this is one of the areas where stability arises. Further, political stability has to be defined and an adequate legal and regulatory framework is also needed (BOA, 2003). Albania is a good example of high growth, low inflation and experiencing growth in the private sector but on the other side there are some important elements of the country's performance that are still lacking behind and that might influence the FDI flow in the country. Therefore, what is currently most important and that should be given priority is the governance and accountability in order to avoid duplicative, complex and non transparent procedures (BOA, 2004).

\section{Time to Enter}

Once a company decides to enter a foreign market he is faced with another dilemma that is that of being the first in the market and consequently benefit from the first mover advantages; or, instead, being a follower and reap the "free - rider" advantages (Makarevitch and Enkel, 2002 ). But however, in most of the cases, a company decides when and where to expand its business overseas upon different market signal which indicate an increase in the venture's valuation. Many academics believe that those firms that enter first in a new market obtain a better position on that market since they have an edge over the other competitors. But on the other hand, another group of authors proclaim that there are many risks associated with the first mover, so in those cases those who benefit are not the pioneers but late entrants (Makarevitch and Enkel, 2002)

Different researches have resulted that there is a strong correlation between the right entry modes and time of entry in a new. But, however, as the literature proclaims the key determining factor that guides any financial institution entry are the profit opportunities. Additionally, order of entry, competitive strategy and performance are closely interrelated with each other and consequently have an impact on the advantages and disadvantages that are associated with being the first or the second mover in the international market (Gaba, et al, 2002). Nevertheless, the host country's market size is another issue that has an influence on the foreign businesses to start their investment overseas. Experience has shown that foreign firms have strategically chosen their timing of entering in a host country, through one of the entry modes previously discussed. Therefore, considering a small host - market size, the foreign firms prefer to 
delay investment there for sufficiently lower threat of entry. Once these foreign firms decide to enter these markets they invest initially with their superior technologies, this time, for sufficiently strong threat of entry (Mukherjee and Mukherjee, 2003)

\section{Conclusions}

It is noted that those foreign banks operating in Albania have a notable experience in other foreign markets. This has positively influenced the development of our banking system.

The phenomenon of expanding banks and financial institutions outside a country's border is being even more frequent in the today's market place. But however, to decide which mode to enter is the most appropriate, several issues should be considered at the same time that are: the motivating and demotivating factors and the right time to enter into this foreign market.

As observed from the study, some motivating factors for expanding in the Albanian market are as follow: limited competition (from domestic and foreign banks) in the market, which lowered their barriers to entry. This situation enabled Greek banks and to obtain a considerable part of this market and at the same time rip all the advantages that the first mover in the market enjoys and consequently building a strong brand name. Even though the banking sector is a politically sensitive issue both for the social and the economic consequences of bank's failures and for their pivotal role in transmitting monetary and financial impulses to the economy and in the implementation of stabilization programs; this situation is somehow positive for multinational banks because a MNB can enter through substantially reduced costs in an emerging market since those countries have been through many financial crises and consequently are very sensitive to foreign entrance.

The entry mode mostly preferred and chosen by MNB entering in Albania has been the sole venture. Reasons behind this choice are maximizing their returns; provide them with fully degree of control over the operations of the branches; better protection of the name of the bank, etc. Important to note is the fact that the reasons that stands behind this choice are almost similar among different businesses. Managers value mostly the degree of control over the branches operations, returns on their investments, as well as they are very carefully that their name overseas is protected and not damaged. For this purpose they chose this entry mode and at the same time they spend a careful attention in selecting their staff.

\section{References}

Bonin, J. P. (2001) Financial Intermediation in Southeast Europe: Banking on the Balkans [online] Available from: http://www.wiiw.ac.at/balkan/files/Bonin.pdf

Bank of Albania (2003) Regulation on Administrators of Banks and Branches of Foreign Banks [online] Supervisory council with the decision No. 120. Available from: www.bankofalbania.org

Buckley, P. J. and Casson, M. C (1998) Analyzing Foreign Market Entry Strategies: Extending the Internationalization Approach. Journal of International Business Studies, Vol.29, Issue 3, Full - text [online] Econlit Database

Claessens, S. and Jansen, M. (2000) The Internationalization of Financial Services: Issues and Lessons for Developing Countries [online] World Bank. Available from: http://www1.fee.uva.nl/fm/papers/Claessens/ chapters/finservices_overview.pdf

Chetty, S. and Hunt, C. C. (2004) A Strategic Approach to Internationalization: A Traditional Versus a "Born - Global" Approach. Journal of International Marketing, Vol. 12, No. 1, pp. 57 - 81. Full - text [online] EBSCO database

Djankov, S., La Porta, R., Lopez de Silanes, F. and Shleifer, A. (2000) The Regulation of Entry [online] Harward Institute of Economic Research. Available from: http://post.economics.harvard.edu/hier/2000papers/ HIER1904.pdf

Gordon \& Glickson LLC (2004) The Globalization of Services: Increasing Success and Mitigating Risk [online] Gordon \& Glickson, Attorneys at Law. Available from:

http://www.mcguirewoods.com/newsresources/publications/technology_business/2004.12.31.pdf

Jiang, F. (2000) Choice between Joint Venture and Sole Venture: The Experience of International Pharmaceutical Firms' Entry Mode Decisions into China [online] International Business. Available from: http://www.hicbusiness.org/biz2003proceedings/Fuming\%20Jiang.pdf [

Malliara, N. (2005) The Expansion of Greek Banks into the Balkans [online]. Available from:http://www.acci.gr/ trade/No34/TRADE_54_56.pdf

Mukherjee, A. and Mukherjee, S. (2003) Foreign Market Entry: a Theoretical Analysis [online]. Leverhulme Centre. Available from: http://www.nottingham.ac.uk/economics/leverhulme/research_papers/03_37.pdf

Makarevitch and Enkel (2002) New Ventures - Important Concepts and Theories [online] Perspectives for our partners in the Competence Center Knowledge Networks for Growth. Available from: 
http://web.iwi.unisg.ch/org/iwi/iwi_pub.nsf/wwwPublAuthorEng/460776076CFF4275C1256E68004B8BE4/\$file/Perspectives\%200 3.pdf

Nijssen, E. J., Douglas, S. P. and Calis, G. (1999) Gathering and Using Information for the Selection of Trading Partners. European Journal of Marketing, Vol.33, 1/2, pp. 143 - 162. Full - text [online] EMERALD database

Taylor, C. R., Osland, G. E. and Zou, S. (2001) Selecting International Modes of Entry and Expansion. Marketing Intelligence \& Planning, Vol. 19, No. 3, pp. 153 - 161. Full -text [online] EMERALD database

Zevros, S. (2004) The Greek Banking Market's Prospects. Trade with Greece. [online], pp. 28-30. Available from: http://www.acci.gr/trade/No16/28-30.pdf 